\title{
Notice of Some Supposed Egyptian Remains, Hitherto Undescribed, in Upper Nubia
}

\section{James Talbot}

To cite this article: James Talbot (1847) Notice of Some Supposed Egyptian Remains, Hitherto Undescribed, in Upper Nubia, Archaeological Journal, 4:1, 139-141, DOI: 10.1080/00665983.1847.10850653

To link to this article: http://dx.doi.org/10.1080/00665983.1847.10850653

册 Published online: 06 Dec 2014.

Submit your article to this journal $[\pi$

Q View related articles $₫$ 


\section{NOTICE OF SOME SUPPOSED EGYPTIAN REMAINS, HITHERTO UNDESCRIBED, IN UPPER NUBIA.}

Egrpt proper ended at Syene, now called Asouan, or the first cataract of the Nile. It appears however that the kings of Egypt held for ages the sway over the narrow skirting of land which stretches above the first cataract. According to Mr. Birch, there are traces of this conquest as early as the 12th dynasty a. The remains of antiquity are very numerous indeed throughout this district, mostly of a date varying from the Ptolemies to the Roman emperors. There are however exceptions, such as Beyt al Wallee, Derr, Seboua, AbooSembel, Samneh, Isle of Argo, and Gebel Barkal. These ruins have been determined to belong to the era of Rameses II., and other kings of the eighteenth dynasty.

At Gebel Barkal, or Napata, the remains are very extensive, and were at one time supposed to represent the site of the ancient Meroe. Major Eelix and the present duke of Northumberland had, however, ascertained the connexion of Thothmes IV., Amenophis III., and Rameses II., all kings of the eighteenth dynasty, with this city, but until the late Prussian expedition the date of no Egyptian monument further to the south had been positively ascertained and communicated to the public.

There are it is true some very interesting monuments of the same style described by Cailliaud at Assur, Mecaou ât, and Naga. The pyramids and extensive ruins at the former place, combined with geographical calculation, leave no doubt of its identity with the ancient Meröe. He has given very minute and elegant representations of these buildings, but unfortunately was not aware of the value of the cartouches for the purpose of fixing their period. In one of his notes he states this circumstance with great regret. Professor Lepsius has supplied this deficiency, as he appears to have examined carefully all the hieroglyphical inscriptions beyond Gebel Barkal. He pronounces the ruins of Assur, Naga, and Meçaourât to be all comparatively recent, not reaching beyond the time of the Ptolemies. At Wady Kerbekan (Cailliaud's Naga), they found a fine statue of one of the kings of the

\footnotetext{
a See his communication to the Royal Society of Literature on the 25th June, 1846.
} 
eighteenth dynasty, but it had probably been transported there. At Wady-Houa-Taib, and Assur, there are many cartouches bearing the names of Osirtesen I., Amenophis III., but evidently of a later period. The same may be said of the other hieroglyphical inscriptions found there.

The most southern point where any antiquities were found by either M. Cailliaud or Dr. Lepsius was Sobah, in lat. 15. $30^{\prime}$, a heap of ruins about half a day's journey above Khartoum, on the eastern bank of the Blue river, once the capital of the Christian kingdom of Aloa. The ruins there are of sunburnt bricks, and evidently Christian. Professor Lepsius however mentions a lion or ram, which is said to have been taken from thence by Khurshid Pasha, and a granite statue of Osiris, of a late style, which they saw at Kamorin, and which had been found at Sobah. M. Cailliaud also mentions a sphinx, which is probably the lion or ram spoken of by the Chevalier Lepsius.

The island of Meroe was bounded by the Blue Nile, the Atbara (the ancient Astaboras), and the Rahad, to the south of Sennaar. It would therefore appear that the four last mentioned ruins were contained in this district, and are the most southerly ones described by any European traveller.

Cailliaud says, (vol. iii. p. 138. 8vo. ed.) "that some Arabs assured him that there were similar ruins at about two days' journey to the south, on the road to Abyssinia ;" he supposes this to be the situation of Mandeyr. He also gives another Arab account, according to which, one and a half day's journey further to the south, are ruins of the same character at a place called Kely. Burckhardt has also alluded to some ruins at a place called Goss-Regiáb, but he was not able to examine them.

These places are all to the north of Sennaar, and appear to be either on the ancient route from Naga to Axum, or the one at right angles to it, that ran from Aboo-Ahraz on the Blue Nile to Souakim on the Red sea.

Even with the assistance of the Arabs, Cailliaud was not enabled to bring the evidence of Egyptian civilization to the latitude of Sennaàr : I am in a position to state on equally good evidence, that there are similar ruins very far south of that city, and near the borders of Abyssinia. I do not wish to be supposed to lay too much stress upon the value of the information which I have received: it has however the ad- 
vantage of most verbal accounts in being altogether voluntary and uncalled for, and as there must be some foundation for the statement ${ }^{b}$, I have thought it my duty to offer this contribution to the interesting subject of African antiquities.

The following is an extract from my journal, 24th Dec., 1840.

"Visited the ruins of the temples of Ombos : they are very fine. I had given a passage in my boat from Asouan to Esne to a slave-merchant, named Hamoud Abd-el-djouad, resident at Asouan. He landed with me, and on seeing the ruins, assured me that he knew of some exactly similar in appearance, but much finer, at a place called Badouka, twelve days' journey beyond Sennaàr, and six hours (about twelve miles) east of the Blue Nile. He had frequently been to Abyssinia by land."

This is pretty clear, and if confirmed would carry the Egyptians close to the borders of Abyssinia. I am afraid we have no evidence for carrying them further. 'The ruins of Axam are doubtless of a much more recent period, belonging either to the Greek or medieval period of Abyssinian history. Vun Heeren hints otherwise, but he does not assign any tangible grounds for his opinions.

JAMES TALBOT.

b The mere fact of worked stone-work being found in such a latitude is sufficient to excite our curiosity. 